которых умирает от дыма, огня и других факторов более 20 тысяч человек. Наибольшее количество человеческих жертв наблюдается в России, Украине и Беларуси. Основная причина гибели людей при пожаре - отравление токсичными газами.

Самым распространенным вредным газом в зоне задымления является углекислый газ $\mathrm{CO}_{2}$. В зависимости от концентрации он может вызывать ускорение и углубление дыхания, раздражение, ощущение сдавливания головы, головную боль, головокружение, замедление пульса, рвоту, потерю сознания и смерть.

В первую очередь пожарные стараются спасти людей. Для этого они должны обладать оперативной информацией о содержании вредных газов в помещении, где находятся люди. Нами разработан мобильный прибор для анализа содержания вредных газов при пожаре. Прибор состоит из 3 функциональных блоков: датчики, микрокомпьютер и система передачи данных.

Сердцем устройства является датчик углекислого газа [1], работающий по технологии NDIR (non-dispersive infrared radiation): излучение инфракрасной лампы в световодной трубке проходит через поток воздуха и попадает на инфракрасный детектор с фильтром. Чем больше в воздушной смеси содержится $\mathrm{CO}_{2}$ - тем сильнее ослабевает инфракрасное излучение, соответственно определяется текущая концентрация $\mathrm{CO}_{2}$. Информация с датчиков подается на микрокомпьютер и передаётся по радиоканалу на мобильное устройство пожарным.

Прибор позволяет производить замеры уровня содержания вредных газов и температуру в помещении дистанционно с применением беспилотных аппаратов. Использовать прибор могут пожарные перед началом эвакуации людей. Мониторинг выявляет содержание вредных газов и позволяет оценить обстановку для принятия решения об алгоритме спасения людей.

1. Козубовский В.Р., Мисевич И.З., Иванчук М.М., Bezpieczenstwo i technika pozarnicza, Centrum Naukowo-Badawcze Ochrony Przeciwpozarowej im. Jozefa Tuliszkowskiego - Panstwowy Instytut Badawczy, 40, 4, c.107-122 (2015).

\title{
METHOD OF RIPE TOMATO DETECTING FOR A HARVESTING ROBOT
}

\author{
Ali W., Ogorodnikova O.M. ${ }^{*}$ \\ Ural Federal University, Yekaterinburg, Russia \\ *E-mail: olga.ogorodnikova@urfu.ru
}

Application of harvesting robots in modern agriculture seems to become a topical trend in smart technologies development due to the possible increasing of productivity at low cost. As for the northern countries, they have their own peculiarities which determine particular features of robots needed for agriculture. First of all, there is a need to grow vegetables in heated and automated greenhouses all year round. Among others, 
tomato is one of the most useful vegetables for growing in greenhouse, and it can be picked up by harvesting robot.

In the current study, an advanced algorithm was proposed for guiding a harvesting robot to pick up ripe tomatoes according to its red colour as the leading criterion of ripeness. Convenient facilities and programming environment of MatLab software package were used to develop and validate the required pattern recognition algorithm on a base of colour processing and other image processing techniques.

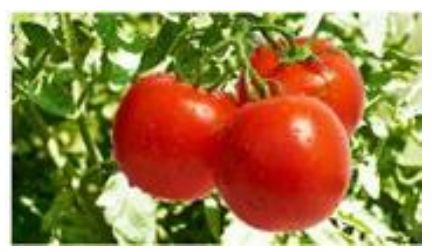

a

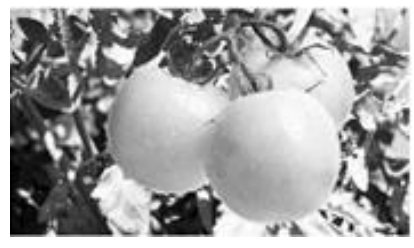

b

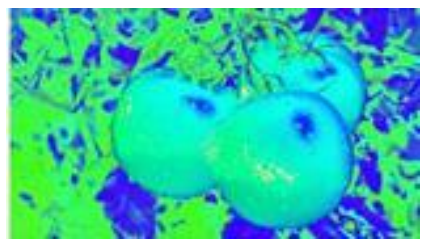

$\mathrm{c}$

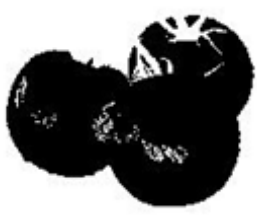

d

Fig. 1. The main stages of image processing for detecting a group of red tomatoes: $a-$ initial image of red tomatoes in greenhouse; $b$ - image of separated red colour; $\mathrm{c}-\mathrm{HSV}$ image; $\mathrm{d}$ - final image of red objects.

Final program code was created and compiled using the preliminary MatLab work to distinguish a group of red round objects from the background of green leaves. The program code contains a number of instructions and functions for reading RGB colour images, converting them to greyscale images, using red bar for processing one colour channel, thresholding the converted images for isolation of the red objects from the green background. Essential morphological operations were also applied to enhance the results. The main stages of image processing for detecting a group of red tomatoes are shown in Fig.1.

\title{
ПРОГРАММНОЕ ОБЕСПЕЧЕНИЕ ДЛЯ ПЕРЕНОСНОГО КАРДИОМИНИТОРА
}

\author{
Бригинец С.А. ${ }^{1 *}$, Веселков А.Ю., Мартынов Г.В.
}

${ }^{1)}$ Северный (Арктический) федеральный университет имени М.В. Ломоносова, г. Архангельск, Россия

*E-mail: briginets.sofya@yandex.ru

\section{THE SOFTWARE FOR FIGURATIVE THE CARDIOMINITORAH}

Briginets S.A. ${ }^{* *}$, Veselkov A.U., Martinov G.V.

${ }^{1)}$ Northern (Arctic) Federal University named after M.V. Lomonosov, Arkhangelsk, Russia

Annotation. For data acquisition from the cardiomonitor, the software is developed. The software allows to read out data from the device and to analyze the received values. Proceeding from the received results, the corresponding signal of a condition of the patient is formed. 